\title{
DESCRIPTION OF THE MALE OF DAGUERREIA INERMIS SOARES \& SOARES, WITH BIOLOGICAL NOTES ON POPULATION SIZE IN THE GRUTA DA LANCINHA, PARANÁ, BRAZIL (ARACHNIDA, OPILIONES, GONYLEPTIDAE)
}

\author{
Ricardo Pinto-da-Rocha ${ }^{1}$
}

\begin{abstract}
The male of Daguerreia inermis Soares \& Soares, 1947, a troglophilic harvestman, is described. Distribution records are given for caves of the Speleological Province of Vale do Ribeira and two non carbonatic areas (Telêmaco Borba and Arapoti, Paraná), in southeastern Brazil. The population of the Gruta da Lancinha (Paraná, Brazil) was studied from October 1988 to February 1989. The population size was estimated, by Fisher Ford's method, between 158-610 individuals. The sex ratio observed was 1:1.

KEY WORDS. Arachnida, Opiliones, Daguerreia inermis, cave fauna, population size
\end{abstract}

The Brazilian cavernicolous harvestmen are represented according to PINTO-DA-RoCHA (1995) mainly by the family Gonyleptidae, but Minuidae, Tricommatidae, Cosmetidae and Stygnidae are also present. Only two troglobite species (obligatory cave dwellings) are recorded, Spaeleoleptes spaeleus H. Soares, 1966 (Minuidae, of the Gruta do Maquiné, Minas Gerais State) and Pachylospeleus strinatii Šilhavý, 1974 (Gonyleptidae, Pachylospeleinae, São Paulo State). The troglophiles (facultative cave dwelling species) are: Pararezendezius luridus $\mathrm{H}$. Soares, 1972 (Tricommatidae, São Paulo State); Daguerreia inermis Soares \& Soares, 1947 (Gonyleptidae, Pachylinae, São Paulo and Paraná States); Eusarcus spp. (Gonyleptidae, Pachylinae, Minas Gerais and Goiás States) and Stenostygnoides caliginosus Pinto-da-Rocha, 1990 (Stygnidae, Pará State). The trogloxenes (cave dwellings who return periodically to surface) belong to Goniosoma spp. (Gonyleptidae, Goniosomatinae, São Paulo and Paraná States) and Paecilaema sp. (Cosmetidae, Goiás State).

Daguerreia inermis SOARES \& SOARES (1947) was described based on a single female from the Gruta de Campinhos (= Gruta dos Jesuítas), Paraná, Brazil. Which was the only record of this species up to the 80 's. Only recently, when intensive collectings were made by Eleonora Trajano, Pedro Gnaspini Netto and the author in the Speleological Province of Vale do Ribeira, this species was newly found. Many invertebrate species in several caves were collected (TRAJANO \& GNASPINI-NETTO 1991a; PINTO-DA-ROCHA 1994), increasing the distribution of $D$. inermis in the Speleological Province of Vale do Ribeira and making possible the description of the male.

1) Museu de Zoologia, Universidade de São Paulo. Caixa Postal 7172, 01064-970 São Paulo, São Paulo, Brasil. 
Daguerreia inermis is troglophile (TRAJANO \& GNASPINI-NETTO 1991a; PINTO-DA-RochA 1994), a cavernicolous facultative species which is able to complete its life cycle within a cave but may also occurrs in ecologically suitable habitats outside the caves (Holsinger \& CULVER 1988).

\section{MATERIAL \& METHODS}

The study was carried out in five visits (02 October, 19 November, 13 December 1988, 17 January and 18 February 1989) in the Gruta da Lancinha $\left(25^{\circ} 19^{\prime} 58^{\prime \prime} \mathrm{S}-49^{\circ} 17^{\prime} 12^{\prime \prime} \mathrm{W}\right)$, a dolomitic cave of Rio Branco do Sul county, Paraná State, Brazil (Fig. 7).

The Gruta da Lancinha has a Y outline, with two main galleries, one crossed by the Lancinha stream $\left(6,218 \mathrm{~m}^{2}\right)$ and another "dry" with large rooms $\left(8,978 \mathrm{~m}^{2}\right)$.

The captures and recaptures was carried out in more than $90 \%$ of the cave. The Gruta da Lancinha was divided in 31 collecting stations, according to the topographic features. This cave area was searched in two steps by the author and an assistant during 7-8 hours/day. In the first step the animals were marked and left a bit of banana, as bait on the ground of each station. During the second time it was marked newly and collected the baits. Several individuals were captured while they were feeding on the bananas although, most of them, while walking on the floor and walls or resting on the walls.

The opilionids were caught by hand and immobilized in a wood plate with rubber band over legs. They were marked with a white droplet of acrylic paint and numbered with black ink, allowing each animal to be recognized individually. These marks were permanent throughout the study, seeming not affecting the locomotion, death or emigration.

Only adults and last nymphal stage of $D$. inermis were used to estimate the population size. The Fisher Ford's method was choose because the number of recaptures of $D$. inermis was very low and the other methods (e.g. Jolly's) can not be used with low rates of recaptures (BEGON 1979).

The studied material is deposited in the following institutions: Museu de História Natural "Capão da Imbuia", Curitiba, Paraná (MHNCI); Museu de Zoologia, Universidade de São Paulo, São Paulo (MZSP, J.L. Moreira Leme); Museu Nacional do Rio de Janeiro, Rio de Janeiro (MNRJ, A. Kury) e Coleção Helia Soares, Universidade Estadual Paulista, Botucatu, São Paulo (HS, R.S. Jim).

All measurements are in millimeters.

\section{RESULTS \& DISCUSSION}

\section{SYSTEMATICS}

\section{Daguerreia inermis Soares \& Soares}

Figs 1-7

Daguerreia inermis Soares \& Soares, 1947: 212, 217, fig. 4. -Trajano \& Gnaspini-Netto, 1991a: 390, 392-395 (distribution). -Gnaspini-Netto \& Trajano, 1994: 561-562, 566-571 (distribution). Pinto-da-Rocha, 1994: 235 (distribution, biology). - Pinto-da-Rocha, 1995: 82 (distribution) 
Pachylospeleinae gen.n sp.n.. - Trajano, 1987: 538-539, 542 (distribution).

Pachylospeleinae; Trajano, 1987: 540, 544 (distribution).

Pachylospeleus sp.n.; Trajano, 1987: 540, 545 (distribution).

Daguerreia sp.; Trajano \& Gnaspini-Netto, 1991b: 75 (biology). - Trajano \& Sánchez, 1994: 534 (distribution).

Note. In a recent article, ACosTA (1996) synonymized Daguerreia Canals, 1933 with Pachyloides Holmberg, 1878 and placed D. inermis as incertae sedis. I agree with Acosta that $D$. inermis does not belong to Pachyloides, based on genital and dorsal scute morphology. However, I'm unable to know if $D$. inerms is belongs to a new genus or to another genus of the Pachylinae. I preferred to maintain the original combination.

Description. Male (MHNCI-6454). Measurements: dorsal scute - 6.42 long, 5.83 wide; cephalothorax: 2.52 long, 3.70 wide. The appendage measurements are in table I.

Table I. Appendage measurements of Daguerreia inermis Soares \& Soares, 1947, male (MNHCl-6454), female holotype (parenthesized).

\begin{tabular}{lccccccc}
\hline & Trochanter & Femur & Patella & Tibia & Metatarsus & Tarsus & Total \\
\hline Pedipalpus & $0.80(0.84)$ & $2.20(2.12)$ & $1.40(1.32)$ & $1.88(1.68)$ & $-(-)$ & $1.36(1.52)$ & $7.64(7.48)$ \\
Leg I & $0.80(0.92)$ & $3.68(3.33)$ & $1.56(1.36)$ & $3.02(2.60)$ & $5.17(4.16)$ & $2.83(2.32)$ & $17.08(14.69)$ \\
Leg II & $0.88(0.96)$ & $8.58(6.33)$ & $2.25(1.80)$ & $6.92(4.64)$ & $9.50(6.58)$ & $8.17(6.00)$ & $36.30(26.31)$ \\
Leg III & $0.96(0.84)$ & $6.42(5.08)$ & $1.92(1.80)$ & $4.33(3.20)$ & $6.25(5.25)$ & $3.42(2.83)$ & $23.30(19.00)$ \\
Leg IV & $1.44(1.00)$ & $8.17(6.58)$ & $2.58(1.92)$ & $5.58(4.67)$ & $9.67(7.33)$ & $3.92(3.42)$ & $31.36(24.92)$ \\
\hline
\end{tabular}

Dorsum (Fig. 1). Dorsal scute pyriform, wider at area II. Anterior margin with a row of minute tubercles. Eye mound high, with few tubercles posteriorly. Cephalothorax with tubercles behind eye mound. Areas I-IV irregularly tuberculate; I divided by a longitudinal median groove. Lateral margin with two rows of tubercles, the external larger. Posterior margin and free tergites with a row of tubercles. Anal plate with several tubercles irregularly distributed.

Venter. Coxa I with a median transverse row of wide tubercles and one posterior smaller; II with two similar rows of tubercles; III with irregularly distributed tubercles; IV, genital and anal opercle tuberculate. Free sternites with a row of minute tubercles.

Chelicera. Segment I with five setiferous tubercles: chelae toothed.

Pedipalpus (Fig. 3). Trochanter with two tubercles. Femur with one ventrobasal and a median row of tubercles, with one prolateral tubercle. Patella unarmed. Tibia with six external and five internal setae. Tarsus with four external and 3-4 internal setae.

Legs. Legs I-IV tuberculate. Coxa I smooth; II with two dorsal tubercles; III with four dorsal tubercles; IV with a high external apophysis with a ventro subapical tubercle, with a short internal apophysis. Femora I-IV straight; III-IV with one prolateral, one retrolateral, two dorsal and two ventral rows of tubercles, ventral tubercles higher near the apex. Tibiae III-IV with a dorsal row of tubercles, one retrolateral, two ventroapical rows of tubercles (Fig. 4). Claws smooth, with tarsal process, without scopulae. Tarsus segmentation: 7(3), 17-18(3), 7, 7. 
Genitalia (Figs 5-6). Ventral plate pyriform, very expanded basally. Lateral margin with four pairs of basal setae and three pairs of distal setae. Dorsal branch of the glans few dilated apically, ventral branch smaller than dorsal, flattened and serrate distally.
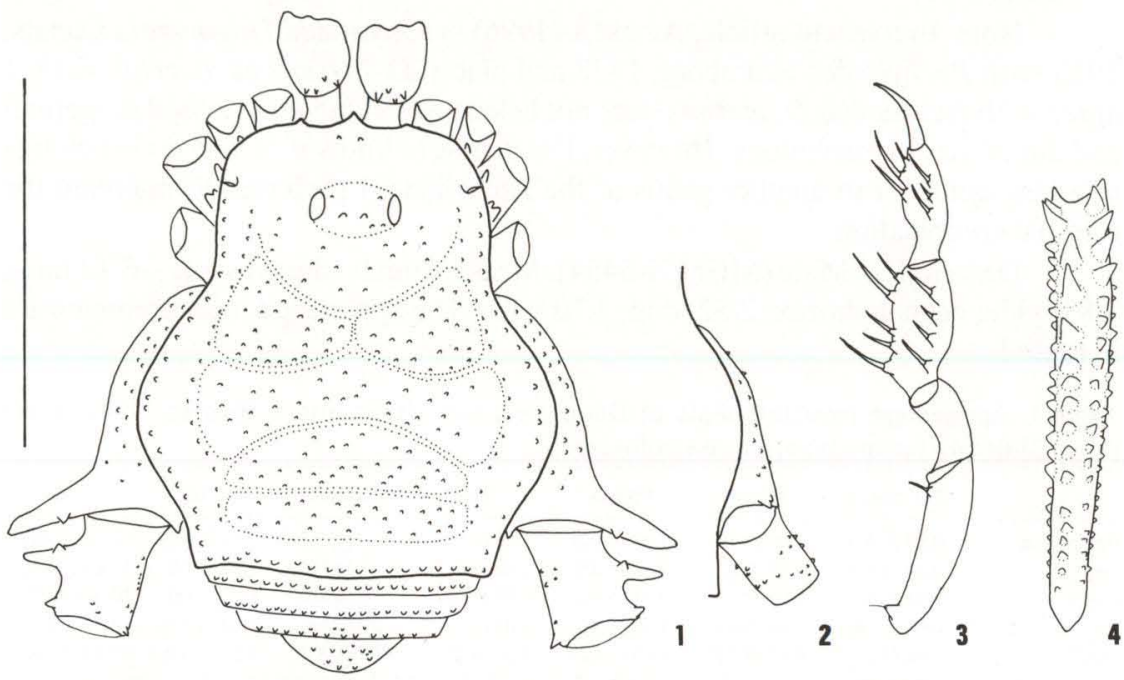

Figs 1-4 Daguerreia inermis Soares \& Soares. (1) Male habitus, dorsal view; (2) female, coxa and trochanter IV; (3) male pedipalpus; (4) male tibia IV. Scale bar $=5.0 \mathrm{~mm}$.
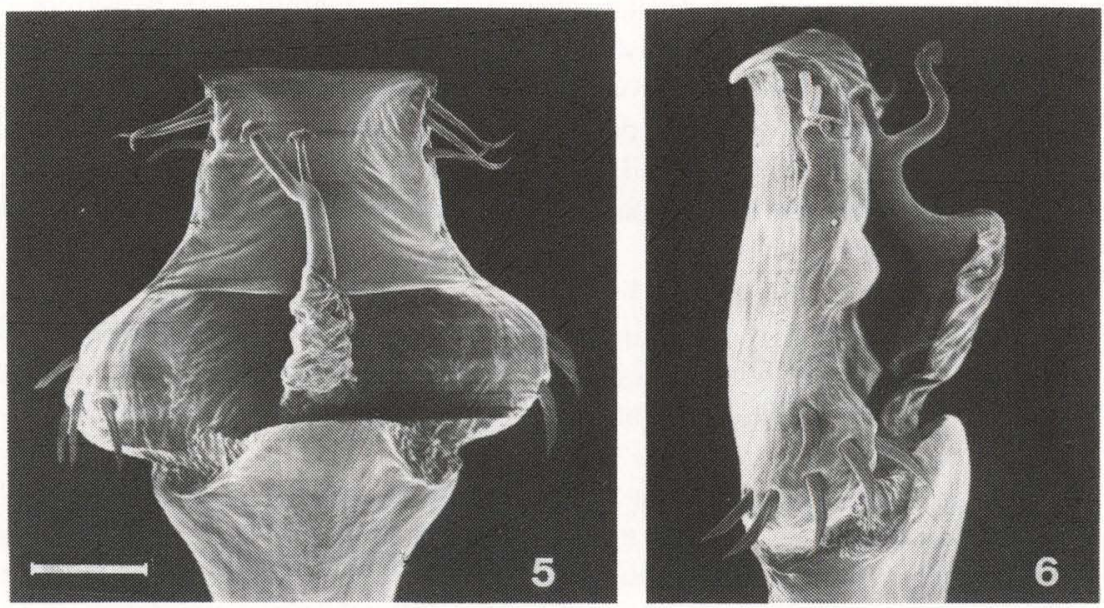

Figs 5-6. Daguerreia inermis Soares \& Soares, scanning micrograph of distal part of penis. (5) Dorsal view; (6) lateral view. Scale Bar $=50 \mu \mathrm{m}$. 


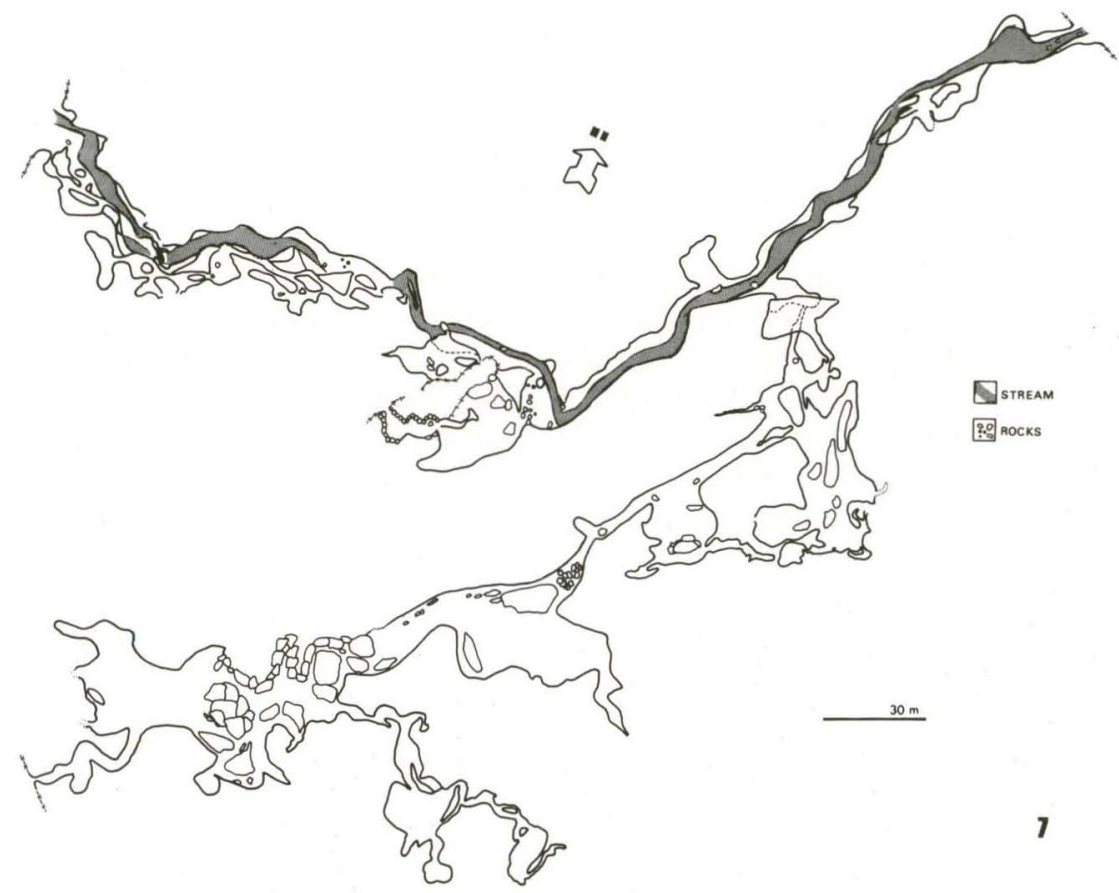

Fig. 7. Horizontal plan of the Gruta da Lancinha, Rio Branco do Sul, Paraná, Brazil.

Color. Cephalothorax reddish brown with several small black spots. Abdomen, chelicera, pedipalpus and legs brownish. Apical apophysis of the coxa IV and tubercles of trochanter IV blackish brown.

Holotype female. Dorsal scute: 6.37 long, 3.68 wide; cephalothorax: 3.13 long, 5.80 wide. The appendage measurements are in table I.

Coxa and trochanter IV (Fig. 2) tuberculate, with small apophysis and small tubercles; coxa IV smaller than male.

Intraespecific variation ( 22 males, 20 females). The number of tarsal segments of tarsi I-IV varies in males $(7-8,14-18,7-8,7-8)$ and in females $(7-8,12-18$, $7-8,7-8)$. The pedipalpus tibia shows $4-5$ external and $4-6$ internal setae and tarsus, 3-4 external and internal setae. The tubercles on the femur III-IV and tibia III-IV varies from $1 / 4$ to the total tibia thickness. The color observed was from yellowish to reddish brown. Dorsal scute length: males 4.32-7.33; females 5.00-7.25. Femur IV lengthened: males 7.33-10.67; females 6.58-10.17.

Geographic distribution. Daguerreia inermis was recorded from many caves in Speleological Province Vale do Ribeira (Atlantic forest and Araucaria forest) and in two counties, Arapoti and Telêmaco Borba (Araucária forest), 135 and $230 \mathrm{~km}$, respectively far from the Vale do Ribeira, where there are no caves. The Speleological Province Vale do Ribeira defined by (KARMANN \& SÁNCHEZ 1986) includes more than 400 caves. 
Material studied. BRAzIL, Paraná: Tunas do Paraná (Gruta de Campinhos), G. Hatschbach leg., I.1945, 1 female holotype (MHNCI-3629); ibidem, R.B. Lange leg., VIII.1947, 1 female (MHNCI-6461); ibidem, R. Pinto-da-Rocha leg., 2.XII.1989, 2 males, 1 female (MHNCI-6646); Castro (Gruta Olhos d'Água), R. Pinto-da-Rocha leg., 14.II.1987, 1 female (MHNCI-6462); ibidem, 2.IX.1990, 1 male (MHNCI-6799); Telêmaco Borba (Harmonia), R. Pinto-da-Rocha leg., 2.XII.1989, 7 males and 7 females (MHNCI-6650); Arapoti (Faz.Barra Mansa), F.C. Straube \& S.A. Morato leg., 22.I.1990, on floor in Araucaria forest, 1 female; (MHNCI-6696); Rio Branco do Sul (Gruta da Lancinha), R. Pinto-da-Rocha leg., 29.III.1986, 1 male and 1 female (MZSP-10564); ibidem, 29.III.1986, 1 male and 1 immature (HS-889); ibidem, 31.V.1987, 1 female (HS-890); ibidem, 2.X.1988, 2 females (MHNCI-6453); ibidem, 17.I.1989, 1 male and 1 female (MHNCI-6454); ibidem, 18.II.1989, 1 male (MHNCI-6455); ibidem, 21.IV.1990, 1 male (MHNCI6755); ibidem (Gruta de Itacolombo), R. Pinto-da-Rocha leg., 28.IV.1990, 1 male (MHNCI-6797); Campo Largo (Gruta de Pinheirinho), R. Pinto-da-Rocha leg., 1.IX.1990, 1 female (MHNCI-6798); (Gruta do Canavial), R. Pinto-da-Rocha leg., 6.XII.1986, 1 male (MHNCI-6459); Almirante Tamandaré (Gruta da Água Boa), R. Pinto-da-Rocha leg., 4.III.1990, 1 male (MHNCI-6757); Iporanga (Caverna Santana), E. Trajano leg., VIII.1981, 1 male (HS-821); ibidem (Caverna Alambari de Baixo), E. Trajano leg., I.1980, 1 male (HS-864); ibidem, 22.IX.1983, 1 female (HS-862); ibidem, 4.II.1984, 1 female (HS-854); ibidem, 22.III.1986, 1 male (HS-892); ibidem (Gruta das Águas Quentes), P. Gnaspini-Netto leg., 2.V.1986, 1 female (HS-897); ibidem, N.M. Godoy leg., 22.X.1983, 1 male (HS-867); ibidem (Gruta Água Suja), E. Trajano leg., 6.IX.1984, 1 male (HS-873); ibidem (Gruta Casa de Pedra), P. Gnaspini-Netto leg., 25.V.1986, 1 male and 1 female (HS-895); ibidem, E. Trajano leg., 4.IV.1985, 1 male and 1 female (HS-861); ibidem, 14.IV.1990, 1 male (MHNCI-6728); ibidem, 29.IV.1990,1 male and 1 female (MHNCI-6729); ibidem (Gruta da Laje Branca), E. Trajano leg., 24.II.1989, 1 male and 1 female (MHNCI-6463); ibidem (Gruta do Fendão), P. Gnaspini-Netto leg., 1.IV.1988, 1 male (HS-893); ibidem (Gruta Colorida), P. Gnaspini-Netto leg., 30.III.1988, 1 male (HS-816); ibidem (Gruta Jane Mansfield), E. Trajano leg., 15.IV.1989, 1 female and 1 immature (MHNCI-6460); ibidem, P. Gnaspini-Netto leg., 3.XII.1988, 1 female and 1 immature, (MHNCI-6450); ibidem (Gruta do Jerivassal), R. Pinto-da-Rocha leg., 8.I.1989, 2 males and 1 female (MHNCI-6264); ibidem (Gruta dos Paivas), E. Trajano leg., 10.II.1989, 1 female and 2 immatures (MHNCI-6262); ibidem (Gruta Teminina II), E. Trajano leg., 26.XI.1989, 1 female (MHNCI-6263); ibidem, 20.V.1989, 1 immature (MHNCI-6457); ibidem, E. Trajano leg., 9.IV.1990, 1 male (MHNCI-6732); ibidem, P. Gnaspini-Netto leg., 1 female and 1 immature (MHNCI-6450); ibidem (Abismo da Chuva), P. GnaspiniNetto leg., 19.IV.1989, 1 male (MHNCI-6458); ibidem, 20.V.1989, 1 immature (MHNCI-6457); ibidem (Caverna Pescaria), E. Trajano leg., 8.IV.1990, 2 males (MHNCI-6724); ibidem (Gruta do Chapéu), E. Trajano leg., 10.IV.1990, 1 male (MHNCI-6730); ibidem (Gruta do Queijo Suiço), 25.XI.1989, E. Trajano leg., 1 male (MHNCI-6758). 


\section{NATURAL HISTORY}

Sex ratio. One hundred and fifty three individuals were captured and marked, including adults and last nymphal stage (without arolium and with complete tarsal segmentation, according to MUÑOZ-CUEVAS 1971) of which 68 were males and 85 females. The sex ratio observed was 1:1 (significant at 0.01 level). The same ratio was observed for the trogloxene Goniosoma spelaeum Mello-Leitão, 1933 (Gonyleptidae, Goniosomatinae) by GNASPINI (1995) and for the troglobite $\mathrm{Pa}$ chylospeleus strinatii Šilhavý, 1974 (Gonyleptidae, Pachylospeleinae) by PINTODA-ROCHA (1996), both from Vale do Ribeira caves.

Population size. One hundred and seventy six individuals were collected and marked and non marked, of which 18 were recaptured (Tab. II). The population size estimated by Fisher-Ford's method was between 158 and 610 individuals (see Tab. II). It was supposed have not occurred emigration/immigration to/or from epigean area based on the lack of records of Daguerreia inermis around the epigean area near the cave; distribution into the cave, even in the aphotic zone (at least $50 \mathrm{~m}$ of the entrances). Another interesting fact is that the forest around the Gruta da Lancinha, composed mainly by "bracatinga" (Mimosa scabrela Benth., Leguminosae), is sawed and burned each seven years to be used at limestone kiln. This phenomena probably kills most of the ground and canopy invertebrates, including harvestmen. However, another kind of emigration is birth and I do not know if the nymphals changed to adults during the study. Four dead non marked individuals were observed in the five months of sampling. This phenomena (emigration/immigration as birth and dead) damages the accurance of the method although I think it does not invalidate the estimate due the few time of sampling (five months). Two other cavernicolous harvestmen had they population size estimated (with different methods and time of sampling): the troglobite $P$. strinatii showed a population estimated between 164 and 236 in the Gruta das Areias de Cima, São Paulo State, Brazil (PINTO-DA-ROCHA 1996) and the trogloxene Goniosoma spelaeum, with populations estimated between six and 246 in six caves of São Paulo State, Brazil (GNASPINI 1996).

Table II. Number of adults and last nymphal stage of Daguerreia inermis captured and released, gain, loss, and population size estimate by Fisher-Ford method in the Gruta da Lancinha, Rio Branco do Sul, Paraná, Brazil, October 1988 to February 1989.

\begin{tabular}{|c|c|c|c|c|c|c|c|c|c|}
\hline \multirow{2}{*}{ Day } & \multirow{2}{*}{ Captured } & \multirow{2}{*}{ Released } & \multicolumn{4}{|c|}{ Recaptured } & \multirow{2}{*}{ Gain } & \multirow{2}{*}{ Loss } & \multirow{2}{*}{$\begin{array}{l}\text { Population } \\
\text { size }\end{array}$} \\
\hline & & & 1 & 2 & 3 & 4 & & & \\
\hline 1 & 9 & 9 & & & & & 0 & 0 & 0 \\
\hline 47 & 34 & 34 & 1 & & & & 387 & 0 & 158 \\
\hline 71 & 37 & 37 & 1 & 1 & & & 27 & 0 & 545 \\
\hline 105 & 49 & 47 & 1 & 3 & 2 & & 38 & 0 & 571 \\
\hline 136 & 47 & - & 0 & 4 & 1 & 4 & 0 & 0 & 610 \\
\hline
\end{tabular}

Survival rate. The survival rate could not be calculated and it was assumed to be 1.0 , as recommend by BEGON (1979). This occurred due the low number of recaptures and probably damage the accurance of population size estimated. 
Distribution. In 14 of the 31 collecting stations nothing was captured, in 10 of them, between 1-10 individuals and in 7, more than 11 individuals. The majority of specimens $(89.55 \%)$ were captured at the Lancinha stream. The distribution is clearly aggregated and the preference by the stream gallery is propably related to the more availability of food (detritus carried into the cave by the stream) in this area. The same was observed by the troglobite $P$. strinatii, which has his population aggregated in the area near the Córrego Grande Stream (PINTO-DA-ROCHA 1996).

Density. The density estimated, considering the estimate of the higher population size ( 610 individuals at $5^{\text {th }}$ day of capture) in $15,196 \mathrm{~m}^{2}$ of the cave was 0.04 individuals $/ \mathrm{m}^{2}$. However, the density varied along the cave. On the stream area $\left(6,218 \mathrm{~m}^{2}\right)$ the opilionids were very common and in "dry galleries" $\left(8,978 \mathrm{~m}^{2}\right)$ they were rare.

Life span. I came back to the Gruta da Lancinha on December 201990 and I found an adult female marked, the droplet was wrinkled and the number inked was unreadable, and consequently it was impossible to identify the month it was captured. This specimen survived at least one year and 10 months as adult (it is impossible to calculate the life time before the $1^{\text {st }}$ capture and how much it will lived after the last capture). The duration of the adult phase was studied for the following Neotropical species: more than two years for the gonyleptid G. spelaeum (MelloLeitão, 1933) (GNASPINI 1995); three to four years for the gonyleptid Pachylus quinamavidensis Muñoz-Cuevas, 1969 (JUBERTHIE \& MUÑOZ-CUEVAS 1971); 2.5 years for the cosmetid Cynorta cubana (Banks, 1909) (JUBERTHIE 1972); and more than three years for the cosmetid Vonones sayi (Simon, 1879) (COKENDOLPHER \& JONES 1991).

Ecological classification and food web notes. Daguerreia inermis is a common opilionid at Ribeira Valley (TRAJANO 1987; TRAJANO \& GNASPINI-NETTO 1991a, 1991b; PINTO-DA-ROCHA 1994, 1995). It was classified as a troglophile since it has been observed in the most of studied cavies as immature in several nymphal stages and adults (showing reproduction at hypogean habitat) and has large cave populations that are distributed for almost all places of the caves. This species was recorded from epigean habitats (Arapoti and Telêmaco Borba) far from the caves and it does not present any morphological specialization for cave life (depigmentation, eye reduction or appendage elongated), usually showed by opilionids. This opilionid is an omnivorous and probably feed on fungi, guano, dead animals and detritus, as hypothesized by TRAJANO \& GNASPINI-NETTO (1991b). In the Gruta da Lancinha, $D$. inermis was frequently observed on or near hematophagous bat guano Desmodus rotundus (E. Geoffroy, 1810) (Phyllostomidae) and on riparian plant debris. Its cave predators (TRAJANO \& GNASPINI-NETTO 1991b) are the spider Ctenus fasciatus Mello-Leitão, 1943 (Ctenidae) and the heteropteran Zelurus travassosi (Costa Lima, 1940) (Reduviidae).

ACKNOWLEDGMENTS. I am grateful to Dr. Eleonora Trajano (IBUSP), Dr. Pedro Gnaspini (IBUSP) and Dr. Sebastião Laroca (UFPR) for the comments on the manuscript and to Dr. Sonia Casari (MZSP) and Dr. Carlos Vilela (IBUSP) for comments on English version. To my 
assistants in cave work Otto Rieppenhoff, Gabriel Skuk, Darci Zakrzewski, Marcos Ricardo Bornschein. To Dr. Alberto Ribeiro and Márcio V. Cruz for the facilities on Laboratório de Microscopia Eletrônica da Universidade de São Paulo. Grant from FAPESP (\# 91/4054-7; 94/1307-0).

\section{REFERENCES}

ACOSTA, L.E. 1996. An emendation of the generic concept of Pachyloides, with the description of a new species (Opiliones, Gonyleptidae, Pachylinae). Revue suisse Zool. Hors (1): 5-14

BEGON, M. 1979. Investigating animal abundance. Londres, Edward Arnold, 96p.

COKENDOLPHER, J.C. \& S.R. JonES. 1991. Karyotype and notes on the male reproductive system and natural history of the harvestman Vonones sayi (Simon) (Opiliones, Cosmetidae). Proc. Ent. Soc. Wash. 93 (1): 86-91.

GNASPINI, P. 1995. Reproduction and postembryonic development of Goniosoma spelaeum, a cavernicolous harvestmen from Southeastern Brazil (Arachnida: Opiliones: Gonyleptidae). Invert. Rep. Dev. 28 (2): 137-151.

1996. Population ecology of Goniosoma spelaeum, a cavernicolous harvestman fro Southeastern Brazil (Arachnida: Opiliones: Gonyleptidae). Jour. Zool. 239: 417-435.

GNASPINI, P. \& E. TRAJANO. 1994. Brazilian cave invertebrates, with a checklist of troglomorphic taxa. Revta bras. Ent. 38 (3/4): 549-584.

HolsingeR, J. \& D. CULVER. 1988. The invertebrate cave fauna of Virginia and a part of Eastern Tennessee: Zoogeography and Ecology. Brimleyana 14: 1-162.

JuberTHIE, C. 1972. Reproduction et développment d'un opilion Cosmetidae, Cynorta cubana (Banks), de Cuba. Ann. Spéléol. 27 (4): 773-785.

Juberthie, C. \& A. MuÑoz-Cuevas. 1971. Sur la ponte de Pachylus quinamavidensis (Opilion, Gonyleptidae). Bull. Soc. Hist. nat. Toulouse 107 (3-4): 468-474.

KARMANN, I \& L.E. SÁNCHEZ. 1986. Speleological provinces in Brazil. In: IX Congresso Internacional de Espeleologia. Barcelona, p.151-153.

MuÑoz-Cuevas, A. 1971. Contribution à l'etude du développement postembryonnaire de Pachylus quinamavidensis Muñoz-Cuevas (Arachnides, Opilions, Laniatores). Bull. Mus. Nat. Hist. Nat. 12 (3): 629-641.

PINTO-DA-RocHA, R. 1994. Invertebrados cavernícolas da Porção meridional da Província Espeleológica do Vale do Ribeira, Sul do Brasil. Revta bras. Zool. 10 (2): 229-255.

- 1995. Sinopse da fauna cavernícola do Brasil (1907-1994). Papéis avulsos Dept. Zool., São Paulo, 39 (6): 61-173.

- 1996. Biological notes and population size of Pachylospeleus strinatii Šilhavý, 1974 in the Gruta das Areias de Cima, Iporanga, southeastern Brazil (Arachnida; Opiliones, Gonyleptidae). Bull. British Arachn. Soc. 10 (5): 189-192.

SOARES, B.A.M. \& H.E.M. SOARES. 1947. Opiliões pertencentes à coleção Gert Hatschbach (Opiliones - Gonyleptidae, Phalangodidae, Phalangiidae). Papéis 
Avulsos Dept. Zool., São Paulo, 8 (18): 209-230.

TRAJANO, E. 1987. Fauna cavernícola brasileira: composição e caracterização preliminar. Revta bras. Zool. 3 (8): 533-561.

Trajano, E. \& P. Gnaspini-NetTo, P. 1991a. Fauna cavernícola brasileira, com uma análise preliminar da distribuição dos táxons. Revta bras. Zool. 7 (3): 383-407.

1991b. Notes on the food webs in caves of southeastern Brazil. Mém. Biospéol. 18: 75-79.

Trajano, E. \& E. SÁnchez. 1994. Brésil, p.527-540. In: Encyclopaedia Biospeologica. Moulis, Societé de Biospéologie, vol. 1.

Recebido em 14.III.1996; aceito em 02.XII.1996. 